Katarzyna Trzeciak

Uniwersytet Jagielloński

\title{
Utopia komunikacyjna w działaniu. Charlotte Perkins Gilman język emancypacyjnej literatury i architektury
}

\section{Abstract \\ Communicational Utopia in Action. Charlotte Perkins Gilman's Language of Emancipatory Literature and Architecture}

The article presents and comments on the activity of Charlotte Perkins Gilman, an American suffragette, writer, and activist for the emancipation of women. The dominant feature of the presentation is a reflection on the project of utopian communication, to which Gilman subordinated her literature and plans for the reform of domestic space. In the essay, I present the issues of language, voice, and status of women's speech, inscribing them into the framework of the communication utopia as an ideal of a rational society.

Słowa kluczowe: sfera publiczna, utopia komunikacyjna, Charlotte Perkins Gilman, rewolucja przestrzeni domowej

Keywords: public sphere, communicational utopia, Charlotte Perkins Gilman, home space revolution 
Zorganizowaliśmy życie tak, że mężczyzna może mieć dom i rodzinę, miłość, bliskość i ojcostwo, pozostając aktywnym obywatelem swojego czasu i kraju. Ale z drugiej strony zorganizowaliśmy życie tak, że kobieta musi „wybrać”, musi albo żyć samotnie, niekochana, pozostawiona sama sobie, pozbawiona wsparcia, bezdzietna, mając za jedyne pocieszenie swoją pracę dla świata, albo zrezygnować z zaangażowania w świat, by cieszyć się miłością, macierzyństwem i domowymi zatrudnieniami.

Zagadnienia komunikacji i języka są ważnym aspektem świata przedstawionego w literackich utopiach, często decydują one o jego odmienności i autonomiczności względem realiów społeczno-historycznych, w których teksty te powstawały. W kanonicznych dla zachodniej kultury utopiach Thomasa More'a i Jonathana Swifta przełamywanie barier obcych języków i alfabetów pozwala stopniowo wprowadzać męskich podróżników do zamkniętych społeczności, funkcjonujących według nieznanych przybyszom reguł komunikacyjnych. Lemuel Guliwer spędza wiele godzin na nauce języka Liliputian, który stawia opór nawet tak wykształconej językowo jednostce, jaką jest posługujący się wieloma językami bohater Swifta: ,[...] a ja przemawiałem do nich we wszystkich językach, których liznąłem choć trochę: po holendersku, niemiecku, łacinie, francusku, włosku, hiszpańsku i w lingua franca, lecz bez skutku"2.

Przezwyciężanie językowych trudności wprowadza bohaterów literackich utopii w obcy świat, pozwala im na coraz pełniejsze istnienie w porządku symbolicznym - rozumienie i artykułowanie abstrakcyjnych znaczeń czy prowadzenie dyskusji o kulturze i sztuce. Problemy z językiem sprowadzają się do kwestii słownika, o czym najlepiej świadczy to, jak Guliwer uczył się lapucjańskiego:

[...] spisałem wielką ilość słów rzędami jedno pod drugim, a równolegle umieściłem ich tłumaczenie. Udało mi się także wyuczyć kilku krótkich zdań. [...] umieściłem w alfabetycznym porządku wszystkie słowa, które mi podano, wraz z ich

1 ,We have so arranged life, that a man may have a home and family, love, companionship, domesticity, and fatherhood, yet remain an active citizen of age and country. We have so arranged life, on the other hand, that a woman must 'choose', must either live alone, unloved, uncompanied, uncared for, homeless, childless, with her work in the world for the sole consolation; or give up all world-service for the joys of love, motherhood and domestic service". Cyt. za: D. Hayden, The Grand Domestic Revolution: A History of Feminist Designs for American Homes, Neighborhoods, and Cities, Cambridge-London 1982, s. 197-198.

2 J. Swift, Podróże do wielu odległych narodów świata, przeł. M. Słomczyński, Kraków 1979, s. 33. 
objaśnieniem. I tak, wspomagany bardzo dobrą pamięcią, uzyskałem w ciągu kilku dni niejaką znajomość ich mowy ${ }^{3}$.

Bohater uczy się przez pamięciowe opanowanie znaczeń wyrazów. Nie poznaje zasad językowego systemu, lecz wyłącznie leksykon, który przyswaja znaną sobie metodą. Języki fantastycznych krain mają u Swifta status typowego języka naturalnego - są dynamicznymi systemami komunikacyjnymi, posiadającymi odmianę ustną i pisemną, obdarzonymi bogatym potencjałem kulturo-, w tym wspólnototwórczym.

W niniejszym szkicu interesować mnie będą przesunięcia w reprezentacjach języka i komunikacji, związane ze szczególnym momentem historycznym i kontekstem społecznym, w którym powstała pewna grupa literackich utopii. Swoją uwagę kieruję ku tekstom pisanym przez kobiety w czasach największej aktywności amerykańskich i brytyjskich sufrażystek. Problem kobiecego głosu i warunków jego społecznego funkcjonowania nie tylko wybrzmiewał w publicznych dyskusjach, lecz także stanowił zwornik dla utopijnych narracji, tematyzujących społeczeństwo kobiecych podmiotowości, widocznych i słyszalnych w intersubiektywnej wspólnocie.

Reprezentantki amerykańskiej i brytyjskiej klasy średniej ${ }^{4}$ uprawiały ten gatunek zarówno po to, by krytykować patriarchalny model społeczny, jak i w celu kompensowania jego opresyjności. Sięgały po utopijne fabuły, gdy na arenach społecznych toczyły się dyskusje nad uznaniem kobiecego głosu, ogniskujące się wokół prawnej interpretacji słowa „człowiek” (man) i „osoba" (person), a zatem dotyczące kwestii języka, znaczenia, reguł komunikacji i materialnej obecności podmiotów w sferze publicznej.

Rzecz jasna, wobec wielości tekstów, powstałych w zróżnicowanym przecież kontekście Stanów Zjednoczonych i Wielkiej Brytanii drugiej połowy XIX i początków XX wieku, powyższe rozpoznanie musi mieć charakter generalizujący i uniwersalizujący. Feministyczne badaczki, zajmujące się od lat siedemdziesiątych XX wieku tymi w większości zapomnianymi tekstami, pisały już o ich różnorodności ${ }^{5}$, wynikającej choćby z odmiennych kulturowych mitologii, mających wpływ na różnice wizji doskonałych społeczeństw Ame-

\footnotetext{
${ }^{3}$ Ibidem, s. $175-176$.
}

${ }^{4}$ Posługując się tym stwierdzeniem, podążam tropem Darby Lewes, badaczki utopii pisanych przez kobiety w latach 1870-1920 w kręgu angloamerykańskim. Lewes wskazuje na ponad sto tekstów napisanych i opublikowanych wówczas przez reprezentantki klasy średniej, które literackie utopie wykorzystywały i do utrwalania swoich wartości oraz światopoglądu, i do wyrażania nadziei na zmianę statusu kobiecego głosu w przestrzeni publicznej. D. Lewes, Dream Revisioners: Gender and Genre in Women's Utopian Fiction 1870-1920, Tuscaloosa, AL, London 1995, s. 2-10.

\footnotetext{
5 A nierzadko i o sprzecznościach pomiędzy nimi.
} 
ryki i Wielkiej Brytanii ${ }^{6}$. Z tego heterogenicznego pola materialno-tekstowych splotów wybieram na potrzeby niniejszego tekstu jedną postać, szczególnie zaangażowaną w utopijny projekt komunikacji literackiej i społecznej. Charlotte Perkins Gilman (1860-1935) jest dla mnie przykładem autorki i aktywistki, która konsekwentnie projektowała utopię sfery publicznej, wymagającą przeobrażenia zarówno samej materialnej przestrzeni, jak i nieodłącznie z nią związanego, symbolicznego wymiaru języka, którym posługują się jej uczestnicy i uczestniczki.

Z perspektywy współczesnej krytyki feministycznej amerykańska pisarka jest postacią kontrowersyjną, a jej wizje i postulaty odzwierciedlają fałszywą świadomość, wynikającą $\mathrm{z}$ anachronicznego uniwersalizowania własnej pozycji oraz nieuświadomionych uprzedzeń, zwłaszcza klasowych i rasowych ${ }^{7}$, a także z naturalizowania macierzyństwa jako niezbywalnego i oczywistego doświadczenia każdej kobiety ${ }^{8}$. Analizy literacko-społecznych projektów Gilman, poświęcone wybranym aspektom proponowanych przez nią rozwiązań, nieuchronnie prowadzą do odkrycia ich niejawnych fundamentów, opartych na stereotypach płci, świadczących o uzależnieniu ich autorki od patriarchalnych determinant. Wyczulone na niuanse i nieufne spojrzenie na teksty amerykańskiej utopistki natychmiast wydobędzie spod powierzchni rzekomo równościowej utopii społecznej ukryte hierarchie, mechanizmy wartościowania i naiwnie spacyfikowane nierówności. I będzie to spojrzenie zasadne.

Chcę jednak przyjrzeć się temu, co Gilman ulokowała na powierzchni swojego projektu i co zdecydowało o słyszalności jej głosu wśród amerykańskiej klasy średniej początku XX wieku. Interesują mnie najbardziej wyraziste cechy literacko-społecznego komunikatu autorki Żóttej tapety ${ }^{9}$ oraz jego znaczenie w mieszczańsko-obywatelskiej sferze publicznej, którą zarazem faktycznie współtworzyła, ale i utopijnie przekształcała.

${ }^{6}$ Wśród najbardziej wyrazistych różnic warto wskazać na odmienność w przedstawieniach przestrzeni. Brytyjskie utopie często opisują przyszłość w technologicznie zaawansowanym Londynie, gdzie kobiety opuszczają przestrzeń domową (rodzinną), wybierając działalność zawodową i publiczną. Amerykanki - co rozwinę w kontekście bohaterki niniejszego szkicu Charlotte Perkins Gilman - kreują przyszłość w odniesieniu do życia rodzinnego i wspólnoty kobiet przekształcających przede wszystkim sferę prywatną. Zob. D. Lewes, op.cit., s. 58; C.F. Kessler, Daring to Dream: Utopian Fiction by United States Women before 1950, Syracuse, NY, 1995, s. xvii.

7 A.E. Weinbaum, Writing Feminist Genealogy: Charlotte Perkins Gilman, Racial Nationalism, and the Reproduction of Maternalist Feminism, „Feminist Studies” 2001, no. 2 (27), s. 272.

${ }^{8}$ L. Evans, ,, You See, Children Were the-the Raison D'être”: The Reproductive Futurism of Charlotte Perkins Gilman's „Herland”, „Canadian Review of American Studies” 2014, no. 2 (44), s. 303.

${ }^{9}$ Ch. Perkins Gilman, Żólta tapeta, przeł. K. Naszkowska, https://www.wysokieobcasy.pl/wysokie-obcasy/ 1,96856, 3900218.html, publ. 6.02.2007 [dostęp: 8.11.2019]. 


\section{Ideał inkluzywnej mowy}

W odróżnieniu od przywołanych na początku kanonicznych utopii pisanych przez mężczyzn pisarki tworzące podczas sufrażyzmu nie tematyzowały językowych trudności ${ }^{10}$. Fikcyjne światy, odwiedzane zgodnie z regułami gatunku przez zewnętrznych wobec nich obserwatorów i obserwatorki, często zaludniały społeczności, których mowa była zrozumiała i jasna dla nowo przybyłych. Taki był język matriarchalnego społeczeństwa kobiet przedstawionego przez Gilman w powieści Herland (1915), stanowiącej drugą część utopijnej trylogii (obok Moving the Mountain [1911] i With Her in Ourland [1916]). Jej narrator, student socjologii, wraz z dwoma towarzyszami odwiedza społeczność kobiet, by zbadać pogłoski o ich życiu w samowystarczalnej, tj. pozbawionej mężczyzn enklawie. Opisując język kobiet, bohater zwraca uwagę na jego brzmienie: „nie był trudny w wymowie, delikatny, przyjemny dla ucha [...] łatwy w czytaniu i pisaniu [...]. Pismo miały ściśle fonetyczne, a całość była sztuczna jak esperanto, choć zarazem nosiła znamiona starej i bogatej cywilizacji" " . Narrator odnosi to wrażenie, przysłuchując się rozmowie matki z dzieckiem, modelowym odbiorcą tej szczególnej mowy. To explicite wizja „matczynego języka”, będąca wykroczeniem przeciwko patriarchalnej genezie ,języka ojca" "12, choć jednocześnie w istocie tylko przesuwająca strukturyzującą zasadę z mężczyzny na dziecko jako „,entralne znaczące”, determinujące możliwość wypowiedzenia kobiecej podmiotowości ${ }^{13}$.

Zmiana źródła języka nie jest wyłącznie właściwością pojedynczej powieściowej fabuły - to dla Gilman projekt totalny, niezbędny punkt wyjścia, by kobiecy głos stał się słyszalny i prawomocny w przestrzeni publicznej.

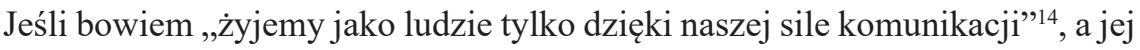
reguły ustala męska władza nad językiem, to niezbędne jest wydobycie innej jego tradycji, osłabiającej męską kontrolę i ukazującej sprawczą rolę kobiet. Ten wysiłek Gilman podejmowała w szkicach poświęconych religii, zwłaszcza w rozprawie His Religion and Hers: A Study of the Faith of Our Fathers

${ }^{10}$ D. Lewes, op.cit., s. 18.

11 ,It was not hard to speak, smooth and pleasant to the ear [...] easy to read and write $[. .$.$] . They had an absolutely phonetic system, the whole thing was as scientific as$ Esparanto [sic! - red.] yet bore all the marks of an old and rich civilization". Ch. Perkins Gilman, Herland [w:] eadem, The Yellow Wall-Paper, Herland, and Selected Writings, ed. D.D. Knight, New York 2009, s. 33.

${ }^{12}$ S. Gilbert, S. Gubar, No Man's Land: The Place of the Woman Writer in the Twentieth Century, vol. I: The War of the Words, New Haven-London 1988, s. 262-271.

13 L. Evans, op.cit., s. 312.

14 „We live, humanly, only through our power of communication”. Ch. Perkins Gilman, The Man Made World, London-Leipsic, OH 1911, b.s. 
and the Work of Our Mothers (1923), w której wywodziła antropologiczną genezę języka z pierwotnych aktywności kobiet - z tradycji mówionej opowieści matczyno-dziecięcej, przeciwstawionej pisanym historiom mężczyzn.

Uznana, androlinearna geneza języka determinuje reguły wytwarzania wypowiedzi, dyscyplinuje kobietę i separuje ją od własnej podmiotowości. Gilman opisała to alienujące doświadczenie $\mathrm{w}$ autobiograficznym opowiadaniu The Yellow Wallpaper (1892) ${ }^{15}$, konstruując bohaterkę zniewoloną męskim, dyscyplinującym dyskursem władzy, ustrukturyzowanym binarnie i hierarchicznie ${ }^{16}$. Projektowany w Herland język matczyny jest niehierarchiczny, bo jego sensotwórczej dynamiki zdają się nie ograniczać żadne arbitralne reguły: znaczenia aktualizują się wraz z rozwojem społeczności, podlegają rozpoznaniom i modyfikacjom pod wpływem kontekstów.

Świetnym przykładem takiej płynności są znaczenia wiązane z męskim zarostem. W świecie kobiet broda i wąsy - tradycyjne znaki męskości - zostają sprowadzone do prostej różnicy fizjonomicznej, a zatem pozbawione kulturowych konsekwencji ${ }^{17}$. Taka „męskość” nie ma mocy hierarchizującej i wartościującej, a odłączona od dyskursu, który zdefiniował jej status, staje się nieoczywista i podległa zmiennym warunkom otoczenia. Tak właśnie dzieje się w chwili, gdy mężczyźni zauważają inne cechy jednego z bohaterów, którego zawsze uznawali za „męskiego”:

W domu porównywaliśmy go z innymi mężczyznami i choć znaliśmy jego słabości, w ogóle nie było w nim nic niezwykłego. Znaliśmy też jego cnoty i zawsze wydawały się bardziej wyraziste niż winy [...]. Na tle kobiet - to znaczy naszych kobiet, w domu - zawsze stał wysoko. [...]

Ale tutaj, wobec spokojnej mądrości i powściągliwego humoru tych kobiet [...] wyraźnie odstawa1 ${ }^{18}$.

15 Zob. przyp. 9.

${ }^{16}$ To wciąż najbardziej znany i najchętniej interpretowany tekst Gilman. Jest on najczęściej czytany jako zapis postępującego szaleństwa kobiety, uwięzionej w domu, a zatem w przestrzeni prywatnej, regulowanej przez niekwestionowaną męską władzę (domowa prywatność wyłączona była z intersubiektywnych regulacji sfery publicznej). Mąż narzuca bohaterce zewnętrzne wobec niej i opresyjne sposoby artykułowania podmiotowości. Fizyczne zamknięcie kobiety współistnieje z symbolicznym, dyskursywnym podporządkowaniem męskiemu językowi.

${ }^{17}$ Ch. Perkins Gilman, Herland..., s. 46.

18 „At home we had measured him with other men, and, though we knew his failings, he was by no means an unusual type. We knew his virtues too, and they had always seemed more prominent than the faults. Measured among women - our women at home, I mean he had always stood high. But here, against the calm wisdom and quiet restrained humor of these women [...], [he - K.T.] did stand out rather strong". Ibidem, s. 75. 
Męskość jest więc kontekstowa, doraźna, a mieszkanki Herland nie rozumieją ,płci męskiej, [...] jej szczególnych wartości, jej niezachwianego przekonania o byciu »siłą życiową «" land eksponuje dialog, przemianę i improwizację, a nie monolityczny, sztywny i zhierarchizowany konstrukt dyskursu patriarchalnego. Język naprawdę staje się heterogenicznym procesem oznaczania" ${ }^{20}$. Nawet fundamentalny akt nazywania, nadawania imion w społeczności kobiet wolny jest od przemocy i arbitralnej niezmienności: „Wraz z upływem życia wiele z nas ma następne imię, opisowe - wyjaśnia jedna $\mathrm{z}$ bohaterek Herland poznającemu krainę mężczyźnie. - Jest to imię, na które się zasługuje. Czasami, gdy życie jest niezwykle bogate, również i to imię się zmienia lub coś się do niego dodaje"21.

Kontakt z językiem świata Herland, gdyby odnieść go do początkowego fragmentu z prozy Swifta, jest więc zetknięciem się z całkowicie odmiennym statusem języka i zasadami produkcji znaczeń. To nie komplikacja alfabetu, lecz fundamentalna odmienność genezy decyduje o komunikacyjnej specyfice społeczności.

Wiele miejsca w utopijnej powieści Gilman zajmują dyskusje przybyszów z mieszkankami krainy, w toku których postawy właściwe obu stronom są konfrontowane i aktualizowane poprzez negocjowanie znaczeń. Mężczyźni są proszeni o wykłady na temat swojego kraju, występują w pozycji autorytetów, ale wyłącznie na zasadach kobiecej społeczności, której reprezentantki nie podporządkowują się hierarchii głosów, lecz publicznie dyskutują z prezentowanymi im opowieściami: słuchaczki zadawały „[...] pytania, które onieśmieliłyby uniwersyteckiego profesora"22. Jak podsumowuje Martha J. Cutter - „W Herland [...] mężczyźni nieustannie uczą się, że nie mogą rządzić za pomocą fallicznego berła władzy i autorytetu"23.

Dominacja języka mówionego, wiele scen żywych dyskusji, a także nieobecność pisanej tradycji i ujętego w piśmie prawa społeczności składają się na kluczową dla Gilman fantazję o równości kobiecego głosu w utopijnie ro-

19 ,Sex, sex with a very large S, he meant the male sex, naturally; its special values, its profound conviction of being »the life force«, its cheerful ignoring of the true life process, and its interpretation of the other sex solely from its own point of view". Ibidem, s. 132.

20 „Rather than the monologic, rigid, hierarchical product that is patriarchal discourse, the musical Herlandian language emphasizes dialogue, transformation, and improvisation. Language truly becomes a heterogeneous signifying process". M.J. Cutter, Unruly Tongue Identity and Voice in American Women's Writing, 1850-1930, Jackson, MS, 1999, s. $121-122$.

${ }^{21}$ „A good many of us have another, as we get on in life - a descriptive one. That is the name we earn. Sometimes even that is changed, or added to, in an unusually rich life". Ch. Perkins Gilman, Herland..., s. 76.

22, ,...] questions as might have intimidated a university professor". Ibidem, s. 66.

${ }^{23}$ „In Herland $[\ldots]$ the men learn repeatedly that they cannot rule with the phallic scepter of power and authority". M.J. Cutter, op.cit., s. 122. 
zumianej sferze publicznej, umożliwiającej wytwarzanie znaczeń, a zarazem wolnej od nierówności i hierarchii. Co istotne, konstrukcja matriarchalnej utopii pokazuje również sposoby wejścia kobiet do tej sfery. Centralną kwestią dla Gilman było uczynienie widocznym i komunikowalnym macierzyństwa, którego izolacja w prywatnej sferze domowej sprzyjała kobiecej niewidoczności i opresji. Sprywatyzowanie życia rodzinnego w opozycji do widzialnej sfery spraw publicznych podtrzymywało nierówności. Ich eliminacja musiała zdaniem autorki Herland wiązać się z konkretnymi rozwiązaniami w życiu kobiet, a zatem ze zmianą warunków, w których ma się realizować projektowana odnowa komunikacji.

\section{Architektura emancypacji}

Popularność Gilman jako reformatorki przestrzeni domowej wiąże się z jej zainteresowaniem kwestiami ekonomicznymi ${ }^{24}$ przełomu XIX i XX wieku. Nierówności majątkowe i zależność finansowa kobiet były dla niej realnym źródłem zniewolenia, które należało wyeliminować nie przez uwolnienie kobiet od życia rodzinnego, jak postulowały niektóre, współczesne jej aktywistki (szczególnie Brytyjki)25, ale usprawniając wypełnianie codziennych obowiązków.

Projekt amerykańskiej reformatorki nie opierał się na polaryzacji pracy i życia rodzinnego, zamianie ról kobiet i mężczyzn, lecz na wizji zniesienia sprzeczności między tymi porządkami i funkcjami:

Nie możemy poruszać się od samotnego domu do obskurnego sklepu i z powrotem, w świecie rozdartym i podzielonym przez egoistyczną produkcję jednej płci

${ }^{24}$ I szerzej - z podjęciem wątków ówczesnych „materialnych feministek” („material feminists"), jak nazywa reformatorki społeczne drugiej połowy XIX wieku Dolores Hayden. W swojej książce The Grand Domestic Revolution: A History of Feminist Designs For American Homes, Neighborhoods, and Cities (Cambridge, MS, London 1982) badaczka przybliża tradycję amerykańskich aktywistek i pisarek, postulujących fundamentalne przeobrażenie przestrzeni (i materialnych warunków życia, przede wszystkim - ekonomicznych) kobiet, niezbędne na drodze do emancypacji.

${ }^{25}$ Porównując utopie literackie Amerykanek i Brytyjek, D. Lewes podkreślała odmienność projektowanych źródeł wolności. Brytyjskie autorki, jak choćby Florence Dixie, przedstawiały swoje bohaterki jako osoby publiczne, oddane działalności zawodowej, politycznej lub społecznej i tworzące ,wielką historię” swojego kraju dzięki porzuceniu domowej przestrzeni i całkowitej rezygnacji z życia rodzinnego. Bohaterka Dixie, Gloriana, zostaje premierką kraju, prowadzi go ku nowym, równościowym czasom, w których publiczna działalność kobiet wypiera ich prywatne życie i domowe zobowiązania (D. Lewes, op.cit., s. 69). 
i równie egoistyczną konsumpcję drugiej. Powinniśmy żyć w świecie kobiet i mężczyzn połączonych swoim człowieczeństwem i seksualnością, pracujących razem, tak jak powinni, dla wspólnego dobra wszystkich ${ }^{26}$.

Pisarka proponowała więc budownictwo mieszkalne ze wspólnymi kuchniami, jadalniami i żłobkami, obsługiwanymi przez wykwalifikowanych pracowników i pracownice, zatrudnianych w przedsiębiorstwach do tego przeznaczonych, ustalających konkretne wynagrodzenia i przejrzyste warunki pracy, o co trudno było, gdy relacje ze służbą pozostawały na poziomie indywidualnych kontraktów każdej rodziny:

Apartamenty nie miałyby swoich kuchni, ale kuchnia byłaby wspólna dla całego budynku, skąd można byłoby serwować posiłki do prywatnych pokoi rodzin lub do wspólnej jadalni, w zależności od życzenia mieszkańców. Wszystkie prace porządkowe wykonywaliby skuteczni pracownicy, zatrudnieni nie przez pojedynczą rodzinę, lecz przez zarządcę całego budynku $[\ldots]^{27}$.

Gilman projektowała zmiany zarówno w wielorodzinnym budownictwie wielkomiejskim, jak i w domach jednorodzinnych na obrzeżach miast. Bez względu na typ zabudowy wskazywała na konieczność przekształcenia kulturowo kobiecych pomieszczeń, indywidualnych i odseparowanych, w miejsca wspólne i otwarte, a także powiększenia części przeznaczonej do wspólnego spędzania czasu - bibliotek, sal gimnastycznych, miejsc pracy i zabawy - do których dostęp mieliby wszyscy mieszkańcy, bez względu na płeć ${ }^{28}$.

Pomysły amerykańskiej działaczki zmierzały więc do przezwyciężenia alienacji kobiet, zamkniętych w izolowanych pomieszczeniach, które - realnie i symbolicznie - tłumiły ich głosy. Otwarcie tych miejsc miało być ciosem wymierzonym w separację i segregację, które architektura może podtrzymywać, ale i - w co wierzyła Gilman - niwelować.

${ }^{26}$,We shall not move from the isolated home to the sordid shop and back again, in a world torn and dissevered by the selfish production of one sex and the selfish consumption of the other; but we shall live in a world of men and women humanly related, as well as sexually related, working together, as they were meant to do, for the common good of all". Ch. Perkins Gilman, Women and Economics: A Study of the Economic Relation Between Men and Women as a Factor in Social Evolution, introd. M. Kimmel, A. Aronson, Berkeley-Los Angeles-London 1998, s. 312.

27 „The apartments would be without kitchens; but there would be a kitchen belonging to the house from which meals could be served to the families in their rooms or in a common dining-room, as preferred. It would be a home where the cleaning was done by efficient workers, not hired separately by the families, but engaged by the manager of the establishment [...]". Cyt. za: D. Hayden, op.cit., s. 189.

${ }^{28}$ Zob. ibidem. 
Dzięki takim rozwiązaniom mieszkanki apartamentów zyskałyby czas na pracę zawodową, a ich rodziny nie straciłyby na nieobecności matek i żon ${ }^{29}$. Nie był to, rzecz jasna, projekt wyjątkowy, Gilman korzystała z rewolucyjnych wizji fourierystów ${ }^{30}$, ale zamiast całkowitej wspólnotowości, eliminującej wszelką prywatność, podsuwała wariant atrakcyjniejszy dla bardziej konserwatywnych obyczajowo kapitalistów - perspektywę lukratywnego przedsiębiorstwa mieszkaniowego działającego według reguł korporacyjnych, a przy tym respektującego mieszczańskie reguły moralności ${ }^{31}$. Jeśli bowiem jej projekt miał trafić do kobiet, których praca zawodowa nie zawsze była społecznie akceptowana, Gilman musiała odciąć się od związków z rewolucyjnymi moralnie ruchami i przedstawić swój program jako idealny dla „szanującej się, monogamicznej rodziny z dziećmi”’32.

To jest prawdziwa droga postępu - uczynienie z pracy domowej legalnej działalności, prowadzonej przez specjalistów, nie amatorów; uczynienie z niej konkretnej gałęzi przemysłu, nie ogólnej kobiecej funkcji i pozostawienie rodzinnej prywatności w prywatnej przestrzeni, do której należy. To nie jest współpraca, ale dobry interes. To jedna z największych możliwości biznesowych, jakie kiedykolwiek widział świat ${ }^{33}$.

Ten krótki fragment $\mathrm{z}$ artykułu prasowego ukazuje pełnię komunikacyjnej skuteczności - Gilman posługuje się retoryką postępu cywilizacyjnego

${ }^{29}$ Ibidem, s. 188-189.

${ }^{30}$ Amerykańscy kontynuatorzy i kontynuatorki tradycji zainicjowanej przez francuskiego socjalistę, Charlesa Fouriera, zainteresowali się przede wszystkim jego wizją mieszkaniowego apartamentowca jako stadium pośrednim między wyizolowanym domem a pozbawiającym prywatności falansterem. Ibidem, s. 73.

${ }^{31}$ Różniło to zrównoważoną perspektywę Gilman od postulatów formułowanych w nieformalnych grupach religijnych, zachęcających do wspólnotowości całkowitej, realizowanych w komunach mieszkalnych, których mieszkańcy i mieszkanki rezygnowali z każdej formy indywidualnej własności i prywatności, także w sferze seksualnej. Gilman była przywiązana do konserwatywnej moralności, dlatego nie podzielała wizji zwolenniczek ruchu „wolnej miłości” (zwłaszcza radykalnej rewizji moralności postulowanej przez Marie Howland, entuzjastkę budownictwa wspólnotowego w duchu socjalizmu Fouriera), którą traktowała jako zagrożenie dla pożądanego rozwoju amerykańskiego społeczeństwa. Ibidem, s. 205.

32 Por. ,[...] respectable, monogamous, married couple with children”. Ibidem, s. 204.

33 „This is the true line of advance; making a legitimate human business of housework; having it done by experts instead of by amateurs; making it a particular social industry instead of a general feminine function, and leaving the private family in the private home where it belongs. This is not cooperation, but it is good business. It is one of the greatest business opportunities the world has ever known". Ch. Perkins Gilman, Why Cooperative Housekeeping Fails, „Harper's Bazar” 1907, vol. XLI, no. 7, s. 627, https://babel.hathitrust. org /cgi/pt?id=mdp.39015008896840\&view=1up\&seq=635 [dostęp: 8.11.2019]. 
i ekonomicznego, a kwestię kobiecą uzgadnia z wymierną logiką kapitału, nie z abstrakcyjną i kruchą ideą ogólnoludzkiej współpracy. Przekonanie o skuteczności takiego modelu pracy Gilman rozpowszechniała także poprzez publikowane w miesięczniku ,The Forerunner" (który sama wydawała w latach 1900-1916) nowele o charakterze dydaktycznym, które często przedstawiały historie zamożnych kapitalistów i kapitalistek inwestujących w domowe przedsiębiorstwa (What Diantha Did, 1910) czy w edukację szkolną dziewcząt (Maidstone Comfort, 1912). Krótkie fikcje Gilman ogniskowały się wokół proponowanych przez nią rozwiązań w zakresie domowej ekonomii i budownictwa mieszkalnego - były schematycznymi fabułami, eksponującymi skuteczność tych propozycji. Realistycznie prowadzone wątki bohaterek pisarka umieszczała na tle utopii urbanistycznych - luksusowych, zaawansowanych technologicznie apartamentów, tworzących wspólnotę mieszkańców i mieszkanek, a przy tym harmonijnie włączonych w środowisko naturalne. Postęp i technologiczny optymizm nie zakładały więc eksploatacji natury, lecz współistnienie z nią, co eliminowało z komunikatu Gilman kolejną źródłową sprzeczność, która zakłócała harmonię organizacji społecznej ${ }^{34}$.

Poszerzenie przestrzeni publicznej w architekturze mieszkalnej nie wymagało również rezygnacji z prywatności (jako intymności życia rodzinnego): „Będą osobne pokoje dla każdego, osobne domy dla rodzin, ale będą także miejsca wspólne" 35 . Przestrzenie ogólnodostępne projektowanych budynków były przeznaczone wyłącznie do wykonywania pewnych jasno określonych czynności (jedzenie, sport, odpoczynek), pozostałe aspekty życia rodzinnego mogły, jak dotąd, rozgrywać się w prywatnych mieszkaniach, gwarantujących prawo do intymności każdej kobiety i jej rodziny.

Formułując swoją wizję architektury uwalniającej kobiety od zamknięcia w domowej przestrzeni, Charlotte Perkins Gilman kierowała się ideą swobody wspólnego uczestnictwa; możliwością, nie przymusem budowania relacji:

Takie środowisko umożliwi nam zgodne ze wspólnym interesem, swobodne współżycie i w jego naturalnym, nieskrępowanym przebiegu rozwiniemy cechy

${ }^{34}$ Szczególną realizacją utopijnego połączenia wątków ekologicznych z postępem technologicznym jest opowiadanie Bee Wise (1913), w którym grupa kobiet buduje w Kalifornii dwa ,racjonalne raje”. Dzięki technologicznemu zaawansowaniu funkcjonują one ekologicznie, pozyskując energię słoneczną, odpowiedzialnie zarządzając zasobami naturalnymi, a przy tym zapewniając sprawiedliwe warunki pracy dla wszystkich kobiet. Zob. D. Lewes, op.cit., s. 161.

35 „There will be the separate rooms for individuals and the separate houses for families; but there will be, also, the common rooms for all". Ch. Perkins Gilman, Women and Economics, s. 314. 
znacznie doskonalsze niż te, których źródłem są niespokojne usiłowania naszego teraźniejszego „społeczeństwa”, byśmy spotykali się nawzajem, nie chcąc tego ${ }^{36}$.

Architektoniczno-komunikacyjny ideał ma u Gilman rodowód oświeceniowo-racjonalistyczny, z którego wynika jej nadzieja na włączenie kobiet w mieszczańską sferę publiczną. Rola architektury jest w jej tworzeniu kluczowa - ochrona przestrzeni prywatnej i zapewnienie wspólnych miejsc spotkań ma gwarantować wspólnotę swobodnego uczestnictwa prywatnych osób, spotykających się i dzięki komunikacji osiągających postęp, także w sferze etyki społecznej. Takie powiększenie przestrzeni publicznej w budynkach mieszkalnych, które nie szkodziłoby intymnym potrzebom jednostek, było wyrazem wiary Charlotte Perkins Gilman w rolę sfery publicznej jako podstawy racjonalnej komunikacji między równymi głosami, dochodzącymi do wspólnych stanowisk dzięki dyskusji, prowadzonej w języku prostym, jasnym i wolnym od hierarchii.

\section{Retoryka utopii, performans konsensusu}

Na każdym poziomie emancypacyjnego projektu autorki Herland fundamentem jest utopijne zniesienie ideologicznych sprzeczności między porządkami społecznej organizacji i ich podstawami. Źródłowej utopii dostarcza literacki obraz z Herland: racjonalnej dyskusji, opartej na jasnym, eliminującym iluzje języku bezpośredniości, która wyklucza przemoc i manipulację. Wiara w elastyczność języka, jego wtórność wobec rzeczywistości zabezpieczała przed normatywizacją pojęć i ustabilizowaniem ich w niezmienne prawa. Nieobecność prawa zakładała więc swobodę współdziałania i dobrowolność uczestniczenia we wspólnocie - inkluzywnej i aktualizowanej doraźnie, dzięki konkretnym rozwiązaniom w budownictwie mieszkaniowym. Dobro wspólne jako główny cel społecznej ewolucji nie stało w sprzeczności z interesami partykularnymi, bowiem Gilman przedstawiała wspólne cele w ramach respektującej liberalne pragnienia retoryki ekonomicznego zysku. Pisarka pacyfikowała więc potencjalne antagonizmy, konsekwentnie pomijała różnice (inne niż różnica płciowa), podtrzymując w swoich wizjach obrazy społecznego konsensusu jako celu racjonalnej dyskusji równoprawnych podmiotów ${ }^{37}$. Uni-

36 „Such an environment would allow of free association among us, on lines of common interest; and, in its natural, easy flow, we should develope far higher qualities than are brought out by the uneasy struggles of our present »society« to see each other without wanting to". Ibidem, s. 314-315.

37 Jak wskazuje Hayden, reforma domowa Gilman, oparta na profesjonalizacji pracy domowej, pomijała kwestie problematyczne dla ówczesnego amerykańskiego społeczeństwa. Różniło ją to od przedstawicielek bardziej radykalnych ruchów kobiecych, które 
wersalne i utylitarne kategorie, którymi posługiwała się amerykańska pisarka - „,dobro wspólne”, , postęp cywilizacyjny”, „rozwój społeczny” - współtworzyły jej retorykę perswazji, dzięki której interesy jednej wyłącznie grupy kobiet, którą reprezentowała (wykształconych, zamężnych, mających dzieci i pracujących poza domem ${ }^{38}$ ), okazywały się fundamentem dobrobytu całego amerykańskiego społeczeństwa. Społeczeństwa, którego podstawowym obowiązkiem - twierdziła Gilman - jest ,postęp, rozwój, [bowiem - K.T.] jesteśmy tu nie po to, by po prostu żyć, ale by wzrastać"39.

Język Perkins Gilman miał wytwarzać wrażenie, że zmiana sytuacji ekonomicznej kobiet jest nie tylko możliwa do przeprowadzenia, ale przede wszystkim, że okaże się też ona korzystna dla ogółu. Aforystyczny, prosty język miał te korzyści poręczać, wybrzmiewając w utopijnie skonstruowanej przez pisarkę sferze publicznej. Dzięki wierze w jej istnienie Gilman mogła formułować swój komunikat, sięgając po „krytyczną retorykę”"40, działającą performatywnie dzięki temu, że używająca jej działaczka nie tylko czerpie z powszechnie uznanych wartości i postaw kobiet, ,ale zastanawia się również nad normami, rozważa relacje władzy i siły, przewartościowuje schematy i tradycję, a także artykułuje siły, mogące zniekształcać rozważania nad ludzkim działaniem"41. O sile Gilman zdecydował więc czysto powierzchniowy efekt języka - komunikacyjna utopia w działaniu.

proponowały inne rozwiązania, jak choćby pełne upublicznienie przestrzeni domowej (i implikowany tym postulatem pomysł ,wolnej miłości”, czyli współdzielenia w sferze seksualnej, analogicznie do współdzielenia pracy domowej) czy - niewygodny dla uprzywilejowanych klasowo kobiet - postulat dobrowolnego, samopomocowego dzielenia się obowiązkami przez gospodynie domowe (w ramach hierarchii klasowych praca domowa w rodzinach kobiet z klasy średniej pozostawała kwestią indywidualnego kontraktu ze służbą). Relacje klasowych hierarchii stanowiły istotną barierę na drodze do zjednoczenia feminizmu i socjalizmu. Perspektywa domowego przedsiębiorstwa i emancypacji kobiet dzięki kapitalistycznym regułom rynku, w które wierzyła Gilman, brzmiała wówczas zachęcająco, nie godziła bowiem w tradycje klasowej hierarchii. Eadem, op.cit., s. 202.

${ }_{38}$ Poprzedzające Gilman amerykańskie reformatorki przestrzeni domowej uwzględniały potrzeby tych grup, które stanowiły liczniejsze grono amerykańskiego społeczeństwa - gospodyń domowych w ogóle lub niezamężnych, pracujących kobiet. Ibidem, s. 203.

${ }^{39}$ Por. „[...] is progress, development; we are here, not merely to live, but to grow". Ch. Perkins Gilman, Women and Economics, s. 207.

${ }^{40}$ To pojęcie - opierając się na ustaleniach Habermasa - można zdefiniować jako retorykę wykraczającą poza akt perswazyjnej mowy w stronę dyskursu praktycznego, który oddziałuje na życie codzienne obywateli i obywatelek danego społeczeństwa. M. Lewis, D. Sebberson, The Rhetoricality of Economic Theory: Charlotte Perkins Gilman and Thorstein Veblen, „Journal of Economic Issues” 1997, no. 2 (31), s. 422.

${ }^{41}$ Por. ,[...] she cannot simply draw on commonly held values and beliefs about women. Instead, she too must deliberate about norms, consider issues of force and power, judge anew in-grained schemata and traditions, and articulate elements of force and power that may distort deliberation and judgment necessary for human action". Ibidem. 


\section{Bibliografia}

Cutter M.J., Unruly Tongue Identity and Voice in American Women's Writing, 18501930, Jackson, MS, 1999.

Evans L., ,Y You See, Children Were the-the Raison D'être”: The Reproductive Futurism of Charlotte Perkins Gilman's „Herland”, „Canadian Review of American Studies" 2014, no. 2 (44), s. 302-319.

Gilbert S., Gubar S., No Man's Land: The Place of the Woman Writer in the Twentieth Century, vol. I: The War of the Words, New Haven-London 1988.

Hayden D., The Grand Domestic Revolution: A History of Feminist Designs for American Homes, Neighborhoods, and Cities, Cambridge, MS, London 1982.

Kessler C.F., Daring to Dream: Utopian Fiction by United States Women before 1950, Syracuse, NY, 1995.

Lewes D., Dream Revisioners: Gender and Genre in Women's Utopian Fiction 18701920, Tuscaloosa, AL, London 1995.

Lewis M., Sebberson D., The Rhetoricality of Economic Theory: Charlotte Perkins Gilman and Thorstein Veblen, „Journal of Economic Issues” 1997, no. 2 (31), s. $417-424$.

Perkins Gilman Ch., Herland [w:] eadem, The Yellow Wall-Paper, Herland, and Selected Writings, ed. D.D. Knight, New York 2009, s. 1-143.

Perkins Gilman Ch., The Man Made World, London-Leipsic, OH 1911.

Perkins Gilman Ch., Why Cooperative Housekeeping Fails, „Harper’s Bazar” 1907, vol. XLI, no. 7, s. 625-627.

Perkins Gilman Ch., Women and Economics: A Study of the Economic Relation Between Men and Women as a Factor in Social Evolution, introd. M. Kimmel, A. Aronson, Berkeley-Los Angeles-London 1998.

Perkins Gilman Ch., Żótta tapeta, przeł. K. Naszkowska, 6.02.2007, https://www. wysokieobcasy.pl/wysokie-obcasy/1,96856,3900218.html [dostęp: 8.11.2019].

Rewers E., Segregacja obcych ciat: porządek i wykluczenie, „Studia Regionalne i Lokalne" 2008, nr 2 (32), s. 5-17.

Swift J., Podróże do wielu odległych narodów świata, przeł. M. Słomczyński, Kraków 1979.

Weinbaum A.E., Writing Feminist Genealogy: Charlotte Perkins Gilman, Racial Nationalism, and the Reproduction of Maternalist Feminism, „Feminist Studies” 2001, no. 2 (27), s. 271-302. 